\title{
UPAYA PANITIA PENGAWAS PEMILU KABUPATEN BANYUMAS DALAM PENCEGAHAN TINDAK PIDANA MONEY POLITIC PADA PEMILIHAN UMUM LEGISLATIF TAHUN 2014
}

\author{
Waslam Makhsid \\ Magister Ilmu Hukum Fakultas Hukum Universitas Jenderal Soedirman
}

\begin{abstract}
The settings in the Law - Law number 15 year 2011 about the election organizers in particular has the authority to supervise the election to run democratically. The research method using sociological juridical approach. Type of research is the study of synchronizing and clinical legal research. The results of the study are presented in the form of narrative text arranged in a systematic, logical and rational. Legal materials were analyzed using qualitative analysis method. Based on the results of the study and discussion of the subject matter presented in this thesis, it can be concluded as follows: The basic tasks and functions of the election monitoring to observe, examine, inspect and examine the legislative elections to be held in accordance with regulations that apply, then the Election Supervisory Committee Banyumas district is required to make an effort in order to overcome the violations and acts criminal money politics. Efforts Election Supervisory Committee Banyumas in preventing the crime of money politics in the implementation of the 2014 Legislative Election is the only electoral oversight by emphasizing preventive action and override aspects. Constraints that cause not maximum effort Election Supervisory Committee Banyumas in preventing the crime of money politics in the Legislative Election 2014 is : (a) Formulation offense and sentencing purposes criminal acts of money politics in laws Legislative Election 2014 is not adequate. Regulation of the crime of money politics is not adequate formulation of aspects of the offense, where the elements of the criminal offense of money politics is cumulative; (b) Election Supervisory Committee that the district has a function as a watchdog organizer Legislative Election 2014 ad hoc and made after running the stages so that the control is not optimal. (c) Factors short statute of limitations Economic and Social Community.
\end{abstract}

Keyword: Panwaslu, Money politic, legislative

\section{ABSTRAK}

Pengaturan dalam Undang-Undang nomor 15 tahun 2011 tentang penyelenggara pemilihan umum yang secara khusus mempunyai kewenangan untuk melakukan pengawasan pemilu agar berjalan secara demokratis, Metode pendekatan yuridis sosiologis (social legal approach). Tipe penelitian adalah penelitian singkronisasi dan penelitian hukum klinis. Sumber data terdiri dari data primer: Hasil penelitian disajikan dalam bentuk teks naratif yang disusun secara sistematis, logis dan rasional. Bahan hukum dianalisis dengan menggunakan metode analisis kualitatif. Upaya Panitia Pengawas Pemilu kabupaten Banyumas dalam mencegah tindak pidana money politic pada pelaksanaan Pemilihan Umum Legislatif tahun 2014 adalah hanya menjalankan fungsi pengawasan pemilu dengan menekankan penindakan dan mengesampingkan aspek pencegahan. Kendala yang menjadi penyebab tidak maksimalnya upaya Panitia Pengawas Pemilu kabupaten Banyumas dalam mencegah tindak pidana money politic pada Pemilihan Umum Legislatif tahun 2014 adalah : (a) formulasi rumusan delik dan tujuan pemidanaan tindak pidana money politic dalam peraturan perundang-undangan. (b) Pemilihan Umum Legislatif tahun 2014 yang belum memadai. Panitia Pengawas Pemilu kabupaten yang mempunyai fungsi sebagai pengawas penyelenggara Pemilihan Umum Legislatif tahun 2014 bersifat ad hoc dan pembentukanya setelah tahapan berjalan sehingga pengawasan tidak optimal; (c) Faktor singkatnya Daluwarsa Penuntutan dan Sosial Ekonomi Masyarakat;

Kata Kunci: Panwaslu, Money Politik, Legislatif

\section{PENDAHULUAN}

Era reformasi yang telah bergulir di Indonesiasejak tahun 1999 menuntut adanya pe- rubahan di segala bidang kehidupan, baik hukum, politik, ekonomi, maupun pemerintahan. Proses demokratisasi dalam suksesi kepe- 
mimpinan nasional maupun kepemimpinan di tingkat pemerintahan daerah serta pembentukan lembaga perwakilan menjadi keharusan yang sulit dihindarkan. Sebagai negara hukum maka kedaulatan rakyat Indonesia dilaksanakan dengan melalui sebuah lembaga/badan perwakilan yang dipilih melalui proses yang demokratis yakni pelaksanaan pemilihan umum dan diatur dalam suatu undang-undang.

Undang-Undang Dasar tahun 1945 sebagai Konstitusi Negara Republik Indonesia yang telah mengalami 4 (empat) kali perubahan, menentukan bahwa pemilihan umum diselenggarakan untuk menyeleksi dan memilih anggota Dewan Perwakilan Rakyat, Dewan Perwakilan Daerah, Presiden dan Wakil Presiden, dan anggota Dewan Perwakilan Rakyat Daerah tingkat provinsi dan kabupaten/kota. Pengaturan secara konstitusional mengenai pemilihan umum tercantum pada ketentuan Pasal 22E Ayat (1) UUD 1945 yang menyatakan bahwa:" Pemilihan umum dilakukan secara langsung, umum, bebas dan rahasia, jujur, dan adil setiap lima tahun sekali". Kemudian diatur lebih lanjut dalam Pasal 22 E Ayat (5) UUD 1945 bahwa:"Pemilihan umum diselenggarakan oleh suatu komisi pemilihan umum yang bersifat nasional, tetap dan mandiri. Selanjutnya mendasarkan Undang-Undang No. 15 tahun 2011 tentang Penyelenggara Pemilu, tentang pengertian Komisi Pemilihan Umum Daerah adalah Komisi Pemilihan Umum Provinsi, Kabupaten/Kota yakni lembaga yang diberi wewenang khusus oleh undang-undang sebagai penyelenggara pemilihan Kepala Daerah dan Wakil Kepala Daerah di setiap provinsi, dan/atau kabupaten/Kota.

Sifat Komisi Pemilihan Umum (KPU) sebagai salah satu penyelenggara pemilihan umum, adalah harus bersifat netral dan tidak memihak serta tidak boleh dikendalikan oleh partai politik ataupun oleh pejabat negara yang mencerminkan kepentingan partai politik atau peserta atau calon peserta pemilihan umum. Mendasarkan UU No. 15 tahun 2011 tentang Penyelenggara Pemilihan Umum, maka dalam rangka penyelenggaraan pemilihan umum, komisi pemilihan umum selaku salah satu penyelenggara diberikan kewenangan untuk membuat peraturan dan keputusan sebagai pelaksana dari undang-undang. Hal tersebut diatur dalam ketentuan pasal sebagai berikut :

Pasal 119 menentukan bahwa :

1. Untuk penyelenggaraan Pemilu, KPU membentuk peraturan KPU dan keputusan KPU.

2. Peraturan KPU sebagaimana dimaksud pada ayat (1) merupakan pelaksanaan peraturan perundang-undangan.

3. Untuk penyelenggaraan Pemilu, KPU Provinsi dan KPU Kabupaten/Kota membentuk keputusan dengan mengacu kepada pedoman yang ditetapkan oleh KPU.

4. Peraturan KPU sebagaimana dimaksud pada ayat (2) ditetapkan setelah berkonsultasi dengan DPR dan Pemerintah.

Pemilihan umum merupakan tempat dan sarana bagi calon anggota Dewan Perwakilan Rakyat/Dewan Perwakilan Rakyat Daerah untuk mendulang perolehan suara dari para konstituennya. Berbagai ragam cara kadang ditempuh oleh seorang calon DPR/DPRD dalam mempengaruhi secara politik mulai cara yang cerdas sampai cara-cara yang kotor (seperti korupsi, suap, money politic dII). Sebagaimana pendapat David M Chalmers yang dikutip oleh Baharudin Lopa, bentuk korupsi meliputi:

1. Political Corruption : bentuk korupsi ini dilakukan orang dalam rangka pemilihan umum untuk mempengaruhi pemilih dengan berbagai cara; 
2. Material Corruption : bentuk korupsi yang memang motifnya mencari materi atau harta benda;

3. Intellectual Corruption : seseorang yang tanpa hak mempublikasikan suatu karangan ilmu pengetahuan (seni, sastra, hasil karya lainya) atas namanya padahal ciptaan orang lain; ${ }^{1}$

Money politik menurut kamus umum bahasa Indonesia mempunyai arti "suap". ${ }^{2}$ Sementara menurut pakar hukum tata negara Yusril Ihza Mahendra, definisi money politic sangat jelas, yakni mempengaruhi massa pemilu dengan imbalan materi. ${ }^{3}$ Dalam kontek penyelenggaraan pemilihan umum lagislatif maka money politic mempunyai makna pemberian sejumlah materi oleh peserta atau kontestan kepada massa pemilih ataupun kepada penyelenggara pemilihan umum yang ditujukan untuk mempengaruhi pilihannya ataupun merubah putusannya.

Pengaturan dalam UU No. 15 tahun 2011 tentang penyelenggara pemilihan umum yang secara khusus mempunyai kewenangan untuk melakukan pengawasan pemilu agar berjalan secara demokratis, juga telah sangat jelas dan terinci. Penyelenggara pemilu yang ditunjuk adalah Badan Pengawas Pemilu (Bawaslu RI), Badan Pengawas Pemilu provinsi (Bawaslu Provinsi), Panitia Pengawas Pemilu kabupaten (Panwaslu kab), Panitia Pengawas Pemilu kecamatan (Panwascam) dan Pengawas Pemilu Lapangan (PPL). Hal itu menunjuk pada ketentuan Bab IV PENGAWAS PEMILU Bagian Kesatu Umum Pasal 69, yang mengatur bahwa :

1) Pengawasan penyelenggaraan Pemilu dilakukan oleh Bawaslu, Bawaslu Provinsi, Panwaslu Kabupaten/Kota,
Panwaslu Kecamatan, Pengawas Pemilu Lapangan, dan Pengawas Pemilu Luar Negeri.

2) Bawaslu dan Bawaslu Provinsi sebagaimana dimaksud pada ayat (1) bersifat tetap.

3) Panwaslu Kabupaten/Kota, Panwaslu Kecamatan, Pengawas Pemilu Lapangan, dan Pengawas Pemilu Luar Negeri sebagaimana dimaksud pada ayat (1) bersifat ad hoc.

Terkait dengan pembentukan, susunan, dan kedudukan Panitia Pengawas Pemilu kabupaten diatur dalam ketentuan Pasal 70 dan Pasal 71. Pada Pasal 70 mengatur bahwa : Panitia Pengawas Pemilu Kabupaten/Kota, Panitia Pengawas Pemilu kecamatan, Pengawas Pemilu Lapangan, dan Pengawas Pemilu Luar Negeri dibentuk paling lambat 1 (satu) bulan sebelum tahapan pertama penyelenggaraan Pemilu dimulai dan berakhir paling lambat 2 (dua) bulan setelah seluruh tahapan penyelenggaraan Pemilu selesai. Selanjutnya Pasal 71 memuat ketentuan :

1. Bawaslu berkedudukan di ibu kota negara.

2. Bawaslu Provinsi berkedudukan di ibu kota provinsi.

3. Panwaslu Kabupaten/Kota berkedudukan di ibu kota kabupaten/kota.

4. Panwaslu Kecamatan berkedudukan di ibu kota kecamatan.

5. Pengawas Pemilu Lapangan berkedudukan di desa atau nama lain/kelurahan.

6. Pengawas Pemilu Luar Negeri berkedudukan di kantor perwakilan Republik Indonesia.

Pada pelaksanaan pemilihan umum anggota Dewan Perwakilan Rakyat Daerah kabupaten Banyumas tahun 2009 terdapat beberapa pelanggaran admistratif maupun pelanggaran

3 Indra Ismawan, Money Politics Pengaruh Uang Dalam Pemilu, Yogyakarta, Penerbit Media Presindo, 1999, hal 4.
Penegakan Hukum, Kompas, Jakarta, hal 68.
Departemen Pendidikan dan Kebudayaan, Kamus Besar
Bahasa Indonesia, Jakarta: Balai Pustaka, Edisi kedua, 1994, hal 965 
pidana pemilu. Pelanggaran administratif seperti yang terjadi dalam tahapan pencalonan adalah : pemilihan umum legislatif 2009 di Kabupaten Banyumas sempat tidak akan diikuti salah satu partai (PDI Perjuangan) atau PDI Perjuangan sebagai peserta pemilu tanpa adanya daftar nama calon legislatif. Kemudian dugaan pidana pemilu adalah pada masa tenang dan pemungutan / penghitungan suara dalam masyarakat juga terjadi pelanggaran berupa adanya dugaan praktik moneypolitic yang tidak elegan. Selama penyelenggaraan Pemilihan Umum Anggota Dewan Perwakilan Rakyat Daerah kabupaten Banyumas tahun 2009 terjadi beberapa kasus money politic yang masuk ke tingkat Panitia Pengawas Pemilu Kabupaten Banyumas ataupun Penegakan Hukum Terpadu (Gakumdu). Dari 10 laporan pelanggaran dugaan money politic yang terjadi selama tahapan masa tenang sampai tahapan pemungutan dan penghitungan suara serta ditangani oleh Panitia Pengawas Pemilu kabupaten Banyumas, pada akhir kesimpulan penanganan terhadap jenis pelanggaran pidana pemilu ini tidak ada yang masuk sampai tingkat pengadilan. Adapun yang menjadi penyebab antara lain adalah tidak adanya cukup bukti, terlapor tidak menghadiri undangan Panitia Pengawas Pemilu kabupaten Banyumas, kadaluwarsa sehingga dugaan perkaranya tidak dapat dilanjutkan ataupun praktik money politic yang ada tidak dilakukan oleh pelaksana kampanye. ${ }^{4}$

Apabila sebuah penyelenggaraan pemilihan umum sebagai pesta besar demokrasi yang dikotori oleh praktik-praktik money politic tentu akan mencederai proses demokrasi itu sendiri. Di

Suharso Agung Basuki, 2010, Tindak Pidana Pemilu Legislatif di Kabupaten Banyumas dan Purbalingga (studi tentang Kebijakan Formulasi dan Penerapan Undang Undang no. 10 Tahun 2008 tentang Pemilu), Tesis, samping itu money politic merupakan kejahatan yang bisa berdampak menimbulkan kejahatan lain pada akhirnya. Berdasarkan uraian tersebut, maka penulis tertarik mengangkat judul tesis tentang Upaya Panitia Pengawas Pemilu kabupaten Banyumas dalam Pencegahan Tindak Pidana Money Politic pada Pemilihan Umum Legislatif Tahun 2014.

\section{METODE PENELITIAN}

Metode pendekatan yang digunakan Yuridis Sosiologis, tipe/tipologi penelitian yang digunakan adalah: Penelitian singkronisasi dan Penelitian hukum klinis, Data yang sudah terkumpul dianalisis dengan menggunakan metode analisis kualitatif.

\section{PEMBAHASAN}

Upaya Panitia Pengawas Pemilu kabupaten Banyumas dalam Pencegahan Tindak Pidana Money Politic pada Pemilihan Umum Legislatif tahun 2014

\section{Tindak Pidana Money Politic}

Money politic atau politik uang dapat juga difahami sebagai pemberian atau janji pemberian sejumlah materi untuk mempengaruhi perilaku atau penggunaan wewenang tertentu. Bentuk - bentuk money politic dalam praktiknya bisa bervariasi. Ada beberapa macam-macam bentuk pemberian uang dari kandidat kepada anggota dewan yang terlibat dengan politik uang (Money Politics). Macam-macam itu adalah sebagai berikut: ${ }^{5}$ (1) Sistem ijon; (2) Melalui tim sukses calon; (3) Melalui

Program Pasca Sarjana Universitas Jenderal Soedirman Purwokerto, hal 98 - 101.

5 Internet, Fenomena Money Politic di Indonesia dalam Perspektif Sosiologi, Tugas Makalah, Jurusan Hubungan 
orang terdekat; (4) Pemberian langsung oleh kandidat; (5) Dalam bentuk cheque.

Di dalam pemilihan umum atau PEMILU ada beberapa praktik tindakan money politic misalnya;

1. Distribusi sumbangan, baik berupa barang atau uang kepada para kader partai, penggembira, golongan atau kelompok tertentu,

2. Pemberian sumbangan dari konglomerat atau pengusaha bagi kepentingan partai politik tertentu, dengan konsesi-konsesi yang ilegal,

3. Penyalahgunaan wewenang dan fasilitas negara untuk kepentingan dan atau mengundang simpati bagi partai poltik tertentu. ${ }^{6}$

Seseorang yang melakukan tindak pidana money politic dapat dijerat dengan pidana. Yusril mengatakan, sebagaimana yang dikutip oleh Indra Ismawan kalau kasus money politic bisa di buktikan, pelakunya dapat dijerat dengan pasal tindak pidana biasa, yakni penyuapan. Tapi kalau penyambung adalah figur anonim (merahasiakan diri) sehingga kasusnya sulit dilacak, ${ }^{7}$ tindak lanjut secara hukum pun jadi kabur.

Tindak pidana money politic yang terjadi selama penyelenggaraan pemilihan umum legislatif termasuk dalam tindak pidana karena merupakan suatu perbuatan yang ada ancaman pidana bagi subyek hukum pelaku yang melakukannya. Pengertian money politic sebagai suatu tindak pidana dalam penyelenggaraan pemilihan umum dapat dijumpai beberapa hukum positif. Salah satu ketentuan yang mengatur adalah dengan melihat ketentuan dalam Pasal 117 ayat (2) UU No. 32 tahun 2004 tentang Pemerintah Daerah sebagaimana telah dirubah

Internasional, Fakultas IImu Sosial dan IImu Politik, Universitas Muhamadiyah Malang dengan Perpu No. 3 tahun 2005. Peraturan tersebut yang menentukan bahwa :

Setiap orang yang dengan sengaja memberi atau menjanjikan uang atau materi lainnya kepada seseorang supaya tidak menggunakan hak pilihnya, atau memilih Pasangan calon tertentu, atau menggunakan hak pilihnya dengan cara tertentu sehingga surat suaranya menjadi tidak sah, diancam dengan pidana penjara paling singkat 2 (dua) bulan dan paling lama 12 (dua belas) bulan dan/atau denda paling sedikit $R p$ 1.000.000,00 (satu juta rupiah) dan paling banyak Rp 10.000.000,00 (sepuluh juta rupiah). Selanjutnya adalah dalam ketentuan Pasal 149 KUHP telah diatur tentang tindak pidana money politic dalam pengertian suap atau pemberian sejumlah uang atau materi tertentu, yakni:

1. Barang siapa pada waktu diadakan pemilihan berdasarkan aturan - aturan umum, dengan memberi atau menjanjikan sesuatu, menyuap seseorang supaya tidak memakai hak pilinnya atau memakai hak itu menurut cara tertentu, diancam dengan pidana penjara paling lama Sembilan bulan atau pidana denda paling banyak empat ribu lima ratus rupiah.

2. Pidana yang sama diterapkan kepada pemilih, yang dengan menerima pemberian atau janji, mau disuap.

Penyelenggaraan Pemilihan Umum anggota Dewan Perwakilan Rakyat, Dewan Perwakilan Daerah, dan Dewan Perwakilan Rakyat Daerah tahun 2014 atau selanjutnya disebut juga sebagai Pemilihan Umum Legislatif tahun 2014 diatur tentang tindak pidana money politic dalam

$6 \quad$ L. Sumartini, S.H, Money Politics dalam Pemilu, Jakarta Badan Kehakiman Hukum Nasional Departemen Kehakiman dan Hak Asasi Manusia, 2004. Hal 148-149 Op cit, Indra Ismawan, Hal 4. 
Undang-Undang yang menjadi paying hukumnya. Peraturan tindak pidana money politic yang dimaksud yaitu mendasarkan ketentuan Pasal 301 UU No. 8 tahun 2012 tentang Pemilihan Umum Anggota DPR, DPD dan DPRD yang menjelaskan bahwa:

1. Setiap pelaksana Kampanye Pemilu yang dengan sengaja menjanjikan atau memberikan uang atau materi lainnya sebagai imbalan kepada peserta Kampanye Pemilu secara langsung ataupun tidak langsung sebagaimana dimaksud dalam Pasal 89 dipidana dengan pidana penjara paling lama 2 (dua) tahun dan denda paling banyak Rp24.000.000,00 (dua puluh empat juta rupiah).

2. Setiap pelaksana, peserta, dan/atau petugas Kampanye Pemilu yang dengan sengaja pada masa tenang menjanjikan atau memberikan imbalan uang atau materi lainnya kepada Pemilih secara langsung ataupun tidak langsung sebagaimana dimaksud dalam Pasal 84 dipidana dengan pidana penjara paling lama 4 (empat) tahun dan denda paling banyak Rp48.000.000,00 (empat puluh delapan juta rupiah).

3. Setiap orang yang dengan sengaja pada hari pemungutan suara menjanjikan atau memberikan uang atau materi lainnya kepada Pemilih untuk tidak menggunakan hak pilinnya atau memilih Peserta Pemilu tertentu dipidana dengan pidana penjara paling lama 3 (tiga) tahun dan denda paling banyak
Rp.36.000.000,00 (tiga puluh enam juta rupiah).

\section{Pencalonan Anggota DPR/DPRD}

Tindak pidana money politic dalam penyelenggaraan pemilihan umum legislatif dapat terjadi pada tahapan pencalonan peserta pemilu yaitu yang dilakukan oleh partai politik, tim sukses ataupun calon anggota DPR/DPRD. Hal ini dimungkinkan apabila ada upaya pemberian sejumlah uang atau imbalan materi lainya yang dilakukan oleh seorang calon legislatif kepada penyelenggara teknis agar proses penetapan sebagai calon mulus ditetapkan memenuhi syarat atau dinyatakan MS (memenuhi syarat), meskipun pada kenyataanya ada syarat administrasi tertentu yang tidak bisa dipenuhi. Pemilihan Umum Dewan Perwakilan Rakyat, Dewan Perwakilan Daerah, dan Dewan Perwakilan Rakyat Daerah tahun 2014 menetapkan bahwa untuk menjadi calon legislatif yang ditetapkan oleh Komisi Pemilihan Umum menjadi DCT (daftar Calon Tetap) harus melalui tahapan yang harus memenuhi berbagai syarat admistrasi.

Adapun syarat yang harus dipenuhi untuk menjadi calon anggota Dewan Perwakilan Rakyat/Dewan Perwakilan Rakyat Daerah mendasarkan ketentuan dalam Pasal 51 Undang Undang nomor 8 tahun 2012 tentang Pemilihan Umum Anggota DPR, DPD dan DPRD.

\section{Upaya Penanggulangan Kejahatan}

Menurut Marc Ancel, criminal policy is the rational organization of the control of crime by society. Apabila diterjemahkan ke dalam bahasa Indonesia pengertian tersebut menjadi, politik kriminal adalah organisasi rasional untuk mengontrol kejahatan dalam masyarakat. ${ }^{8}$ 
Pandangan lain disampaikan oleh Hoefnage $l^{9}$, bahkan ia memberikan lebih dari satu pengertian dari pada politik kriminal. Beberapa pengertian tersebut adalah;

1. Criminal policy is the rational organization of the social reaction to crime (politik kriminal adalah organisasi rasional dari reaksi sosial terhadap kejahatan).

2. Criminal policy is the science of crime prevention (politik kriminal adalah ilmu pengetahuan mengenai pencegahan kejahatan).

3. Criminal policy is a policy of designating behavior as a crime (politik kriminal adalah kebijakan dalam rangka menandai perilaku sebagai suatu kejahatan).

4. Criminal policy is a rational total ofresponse to crime (politik criminal adalah rasional total dari respon terhadap kejahatan).

Mulder mengemukakan bahwa kebijakan hukum pidana ialah garis kebijakan yang menentukan :

a. Seberapa jauh ketentuan-ketentuan pidana yang berlaku perlu diubah atau diperbaharui;

b. Apa yang dapat diperbuat untuk mencegah terjadinya tindak pidana;

c. Cara bagaimana penyidikan, penuntutan, peradilan, dan pelaksanaan pidana harus dilakukan. ${ }^{10}$

Mendasarkan skema politik kriminal menurut G.P. Hoefnagels, usaha untuk menanggulangi kejahatan dalam politik kriminal dapat dijabarkan melalui: ${ }^{11}$

1. Penerapan hukum pidana (criminal law application);

2. Pencegahan tanpa pidana (prevention without punishment); dan
3. Mempengaruhi pandangan masyarakat mengenai kejahatan dan pemidanaan lewat media massa (influencing view of society on crime and punishment).

\section{a. Pendekatan Penal}

Pendekatan penal merupakan upaya pencegahan tindak pidana yang dilakukan dengan menggunakan sarana pidana atau ancaman pidana, pendekatan penal ini merupakan pendekatan yang paling awal dalam pidana. Menurut Gene Kassebaum disebut sebagai pendekatan paling tua karena keberadaanya setua peradaban manusia itu sendiri, sehingga ia mengatakan bahwa sarana penal merupakan "older philosophy of crime control". ${ }^{2}$ Sarana pidana digunakan sebagai upaya paksa dalam penegakan hukum pidana melalui sistem peradilan pidana. Mencermati pendapat Mardjono Reksodiputro bahwa sistem peradilan pidana adalah sistem pengendalian kejahatan yang terdiri dari lembaga kepolisian, kejaksaan, pengadilan, dan pemasyarakatan. ${ }^{13}$

Pendapat tersebut sejalan dengan pandangan dari Barda Nawawi Arief yang mengungkapkan bahwa sistem peradilan pidana pada hakikatnya identik dengan sistem penegakan hukum pidana ataupun sistem kekuasaan kehakiman di bidang hukum pidana, terpadu diimplementasikan dalam 4 (empat) sub-sistem kekuasaan, yaitu kekuasaan penyidikan, kekuasaan penuntutan, kekuasaan mengadili/ menjatuhkan pidana, dan kekuasaan eksekusi/pelaksanaan pidana. ${ }^{14}$
9 Widiada Gunakaya dan Petrus Irianto, 2012, Kebijakan Kriminal Penanggulangan Tindak Pidana Pendidikan, Alfabeta, Bandung, hal 10.

10 Barda Nawawi Arief, Op.cit, hal 28 - 29.

11 Ibid, hal $39-40$

12 Muladi dan Barda Nawawi Arief, 1984, Teori-Teori dan Kebijakan Pidana, Alumni, Bandung, hal 149.
13 Mardjono Reksodiputro, 1993, Sistem Peradilan Indonesia (Melihat Kepada Kejahatan Dan Penegakan Hukum Dalam Batas-Batas Toleransi), Pidato Pengukuhan Guru Besar IlmuHukum pada Fakultas Hukum Universitas Indonesia, Jakarta, hal 1.

${ }^{14}$ Barda Nawawi Arief, 2007, Kapita Selekta Hukum Pidana, Universitas Diponegoro, Semarang, hal 9. 


\section{b. Pendekatan Non Penal}

Pencegahan dan penanggulangan tindak pidana dalam politik kriminal, di samping melalui sarana penal dapat dilakukan dengan menggunakan sarana non penal. Penggunaan sarana non penal sangat berkaitan erat dengan pencegahan sebelum terjadinya tindak pidana, sementara pendekatan dengan sarana penal adalah dilakukan setelah terjadinya tindak pidana serta untuk mencegah supaya tidak terjadi pengulangan tindak pidana di kemudian hari. Tujuan dari pendekatan non penal adalah perbaikan kondisi sosial tertentu serta termaktub upaya preventif terhadap tindak pidana. Menurut Barda Nawawi Arief menyampaikan bahwa :15

"Pendekatan ini memiliki tujuan utama untuk memperbaiki kondisi-kondisi sosial tertentu, namun secara tidak langsung mempunyai pengaruh preventif terhadap kejahatan. Dengan demikian menuurut Barda Nawawi Arief, pendekatan non penal dalam politik kriminal memiliki posisi yang sangat startegis dan memegang posisi kunci yang harus diintensifkan dan diefektifkan, apabila pendekatan ini mengalami kegagalan dalam penggarapannya justru akan berakibat fatal bagi usaha menanggulangi kejahatan."

Urgensi penggunaan sarana non penal dalam pencegahan tindak pidana adalah adanya keterbatasan dan kekurangan yang terdapat dalam sarana penal. Banyak sarjana yang menyampaikan pendapatnya tentang keterbatasan sarana penal dalam pencegahan tindak pidana, antara lain:

1. Rubin, menyatakan bahwa pemidanaan (apapun hakikatnya apakah dimaksudkan untuk menghukum atau memperbaiki) sedikit atau tidak mempunyai pengaruh terhadap masalah kejahatan;
2. Karl O. Christiansen, menyatakan bahwa kita mengetahui pengaruh pidana penjara terhadap si pelanggar, tetapi pengaruh pengaruhnya terhadap masyarakat secara keseluruhan (generalprevention) merupakan "terra incognita", suatu wilayah yangtidak diketahui (unknown territory).

3. S. R. Brody, menyatakan bahwa dari Sembilan penelitian mengenai pemidanaan, lima diantaranya menyatakan bahwa lamanya waktu yang dijalani di dalam penjara tampaknya tidak berpengaruh pada adanya penghukuman kembali (reconviction)

4. Bassiouni pernah menegaskan bahwa kita tidak tahu atau tidak pernah tahu secara pasti metode-metode tindakan (treatment) apa yang paling efektif untuk mencegah dan memperbaiki atau kita pun tidak mengetahui seberapa jauh efektivitas setiap tindakan itu untuk dapat menjawab masalahmasalah secara pasti, kita harus mengetahui sebab - sebab kejahatan dan untuk mengetahui hal ini kita memerlukan pengetahuan yang lengkap mengenai etiologi tingkah laku manusia. ${ }^{16}$

Pencegahan tindak pidana sebagai essensi sarana non penal dapat diartikan sebagai tujuan utama politik kriminal. Mengingat konsep dan definisi dari suatu pencegahan masih lemah, sehingga wacana perdebatan pencegahan tindak pidana dibatasi dalam kerangka pendekatan dan model.

"Secara tradisional, tujuan system peradilan pidana bersifat represif dan berkaitan erat dengan pencegahan kejahatan setelah suatu kejahatan terjadi (after onofffence has already occurred). Konsep pencegahan kejahatan sendiri memfokuskan diri pada campur tangan sosial, ekonomi, dan pelbagai area kebijakan publik, dengan maksud mencegah kejahatan sebelum kejahatan 
dilakukan (to prevent crime before an offence has been committed). ${ }^{17}$

\section{Kendala Upaya Panitia Pengawas Pemilu kabupaten Banyumas dalam Pencegahan Tindak Pidana Money Politic pada Pemilihan Umum Legislatif tahun 2014}

\section{Tujuan Pemidanaan}

Setiap pemidanaan mempunyai tujuan pemidanaan baik untuk pembalasan, pembinaan maupun pencegahan perilaku yang anti sosial. Tujuan Pemidanaan dapat diidentifikasikan mendasarkan teori - teori tentang pemidanaan. Teori tentang pemidanaan sendiri dapat dibedakan menjadi 2 (dua kajian), yakni teori tujuan pemidanaan yang tradisional (klasik) dan tujuan pemidanaan menurut teori yang menitik beratkan pada perlindungan masyarakat. Secara tradisional teori pemidanaan pada umumnya dibagi dalam 3 (tiga) kelompok teori, yaitu: (1) Teori Absolut atau teori pembalasan (retributive / velgedeng theorien); (2) Teori Relatif atau teori tujuan (utilitarian atau doeltheorieen); (3) Teori Gabungan (verenigings theorieen). ${ }^{18}$

\section{Teori Absolut}

Menurut teori absolut, pidana dijatuhkan semata-mata karena orang telah melakukan suatu kejahatan pidana. Pidana merupakan akibat mutlak yang harus ada sebagai suatu pembalasan kepada orang yang melakukan kejahatan. Dasar pembenaran dari pidana menurut teori absolut ini, terletak adanya atau terjadinya kejahatan itu sendiri.

\section{Teori Relatif atau teori tujuan (utilitarian atau doeltheorieen)}

Teori relatif berusaha mencari dasar pembenaran dari suatu pidana, semata-mata pada suatu tujuan tertentu. Para penganjur teori relatif ini tidak melihat pidana sebagai suatu pembalasan, dan tidak mengakui bahwa pemidanaan itu merupakan tujuan pemidanaan, melainkan pemidanaan itu merupakan adalah suatu cara untuk mencapai suatu tujuan yang lain dari pemidanaan itu sendiri. Dengan demikian oleh karena pemidanaan mempunyai tujuan, maka teori ini sering disebut juga dengan teori tujuan (utilitarian theory). Jadi dasar pembenaran adanya pidana pidana menurut teori tujuan terletak pada tujuannya. Pidana dijatuhkan bukan karena orang berbuat jahat melainkan supaya orang jangan melakukan kejahatan. ${ }^{19}$

\section{Teori Gabungan (verenigings theorieen)}

Penulis pertama yang mengajukan teori gabungan adalah Pellegrino Rosi (1787 -1848), yang mengatakan bahwa pembalasan sebagai asas pidana dan beratnya pidana tidak boleh melampaui suatu pembalasan yang adil, dan teori ini juga berpendirian bahwa pidana mempunyai berbagai pengaruh antara lain perbaikan sesuatu yang rusak dalam masyarakat dan prevensi general. ${ }^{20}$

\section{Bekerjanya Hukum}

Dalam kehidupan bermasyarakat, maka regenerasi atau penerapan hukum itu hanya dapat terjadi melalui manusia sebagai perantaranya. Masuknya faktor manusia ke dalam pembicaraan tentang hukum itu, membawa 
kepada penglihatan mengenai hukum sebagai karya manusia di dalam masyarakat, maka tidak dapat membatasi masuknya pembicaraan mengenai faktor-faktor yang memberikan beban pengaruhnya terhadap hukum yang meliputi pembuatan hukum, pelaksanaan hukum, dan nilai-nilai dalam masyarakat.

Hukum agar bisa berfungsi sebagai sarana rekayasa sosial bagi masyarakat biasa dan masyarakat pejabat sebagai pemegang law enforcement, maka dapat dipakai pendekatan dengan mengambil teori Robert Seidman yang menyatakan bahwa bekerjanya hukum dalam masyarakat itu melibatkan tiga kemampuan dasar, yaitu pembuat hukum (Undang-undang), birokrat pelaksana dan masyarakat obyek hukum. Pelaksana hukum, perilakunya ditentukan pula peranan yang diharapkan daripadanya. Namun bekerjanya harapan itu tidak hanya ditentukan oleh peraturan-peraturan saja, melainkan juga oleh faktor-faktor lainnya, tapi juga oleh: (1) Sanksi - sanksi yang terdapat didalamnya; (2) Aktifitas dari lembaga - lembaga atau badan-badan pelaksana hukum; (3) Seluruh kekuatan sosial, politik dan lainnya yang bekerja atas diri pemegang peran itu.

Kondisi masyarakat yang mempunyai perbedaan status sosial, ekonomi dan budaya sangat berpengaruh dalam pencegahan dan penindakan praktik money politic. Fenomena diatas merupakan fenomena perilaku hukum yang diskriminatif. Sebagaimana menurut Donald Black bahwa ada 5 faktor yang menjadi penyebab diskriminatif hukum yaitu: ${ }^{21}$

Stratifikasi sosial : ketidak samaan kekayaan dan sumber daya; (2) Morfologi sosial : pola pola hubungan antar personal; (3) Kultur : perilaku simbolik; (4) Organisasi : derajat dimana dimobilisasi dalam tindakan kolektif ; (5) Pengendalian sosial lain di luar hukum : sifat atau tingkatan dari mekanisme mekanisme non hukum bagi pendefenisian dan tanggapan terhadap suatu tindakan salah (wrong doing).

Dengan adanya perilaku hukum yang diskriminatif tersebut maka akan nampak jelas bahwa hukum yang tercantum di dalam undangundang akan berbeda dari pada hukum sebagai perilaku. Kondisi tersebut dimungkinkan menjadikan sebagai faktor-faktor yang semakin menyuburkan praktik money politic yang terjadi dalam masyarakat selama penyelenggaraan Pemilihan Umum Legislatif tahun 2014. Kondisi yang terjadi menunjukan bahwa hukum positif yang mengatur dan terkait dengan tindak pidana money politic tidak dapat bekerja atau tidak dapat berlakukan secara efektif dalam masyarakat. Untuk itu sangat diperlukan adanya upaya yang sangat extra untuk membangun kesadaran hukum masyarakat yang diimbangi upaya memberikan kesejahteraan dan keadilan bagi masyarakat.

\section{PENUTUP}

\section{Simpulan}

Upaya Panitia Pengawas Pemilu kabupaten Banyumas dalam mencegah tindak pidana money politic pada pelaksanaan Pemilihan Umum Legislatif tahun 2014 adalah hanya menjalankan fungsi pengawasan pemilu dengan menekankan penindakan dan mengesampingkan aspek pencegahan, yakni:

Pertama, Pembentukan panitia pengawas pemilu secara berjenjang seperti hanya mem-

21 H. M. Tarid Palimari, S.H., Mewujudkan Penegakan Hukum yang Bermartabat, artikel internet,. 
181 Jurnal Idea Hukum

Vol. 1 No. 2 Edisi Oktober 2015

Magister Hukum Fakultas Hukum Universitas Jenderal Soedirman

bentuk panitia pengawas pemilu kecamatan dan petugas pengawas lapangan.

Kedua, Melakukan pengawasan terhadap tahapan penyelenggaraan Pemilihan Umum Legislatif tahun 2014 yang mencakup: pencalonan, kampanye, masa tenang dan pemungutan suara.

Ketiga, Melakukan fungsi penindakan dengan memeriksa serta mengkaji temuan atau laporan tindak pidana money politic yang terjadi dalam penyelenggaraan Pemilihan Umum Legislatif tahun 2014.

Kendala yang menjadi penyebab tidak maksimalnya upaya Panitia Pengawas Pemilu kabupaten Banyumas dalam mencegah tindak pidana money politic pada Pemilihan Umum Legislatif tahun 2014 adalah :

Pertama, Formulasi rumusan delik dan tujuan pemidanaan tindak pidana money politic dalam peraturan perundang-undangan Pemilihan Umum Legislatif tahun 2014 yang belum memadai. Regulasi tindak pidana money politic belum memadai dari aspek formulasi deliknya, di mana unsur-unsur delik pidana money politic bersifat komulatif. Di samping itu ancaman pidana yang ada masih sangat rendah dan belum mengandung aspek tujuan pemidanaan sehingga belum menimbulkan efek jera dalam masyarakat.

Kedua, Panitia Pengawas Pemilu kabupaten yang mempunyai fungsi sebagai pengawas penyelenggara Pemilihan Umum Legislatif tahun 2014 bersifat ad hoc dan pembentukanya setelah tahapan berjalan sehingga pengawasan tidak optimal. Kondisi dan keberadaan Panitia Pengawas Pemilu kabupaten tersebut juga tanpa didukung dengan adanya penguatan secara personel kelembagaan, ketersediaan dana dan sarana pra sarana maupun operasional pelaksanaan pengawasan yang memadai.

Keempat, Faktor singkatnya Daluwarsa Penuntutan dan Sosial Ekonomi Masyarakat. Daluwarsa waktu untuk melakukan kajian pemeriksaan terhadap temuan dan laporan masyarakat tentang tindak pidana money politic oleh panitia pengawas pemilu kabupaten terlalu sempit hanya untuk klarifikasi tidak mencukupi.

Kelima, Minimnya sosialisasi yang dilakukan oleh Panitia Pengawas Pemilu kabupaten dalam penyelenggaraan Pemilihan Umum Legislatif tahun 2014 dan penggunaan sarana non penal yang belum optimal untuk melakukan pencegahan tindak pidana money politic. Panitia Pengawas Pemilu Kabupaten tidak mempunyai kewenangan lain untuk menerapkan hukum pidana money politic secara progresif.

\section{Saran}

Pertama, Perlu mereformulasi tindak pidana money politic, misalnya rumusan delik pidana money politic bisa diberlakukan secara alternatif dengan ancaman pidana yang berat sehingga aspek tujuan pemidanaan terlingkupi serta dapat menimbulkan efek jera di masyarakat sebagai sarana penal dalam upaya pencegahan tindak pidana money politic dalam penyelenggaraan Pemilihan Umum Legislatif. Pencegahan melalui sarana non penal adalah dengan Panitia Pengawas Pemilu perlu melakukan sosialisasi dan media campaigne secara masiff agar masyarakat menolak money politic dalam peneyelenggaraan Pemilihan Umum Legislatif.

Kedua, Panitia Pengawas Pemilu kabupaten perlu mendapatkan penguatan kelembagaan ataupun secara personel sehingga perlu didorong menjadi penyelenggara Pemilihan 
Umum Legislatif yang tetap sebagaimana Komisi

Pemilihan Umum kabupaten.

\section{DAFTAR PUSTAKA}

\section{Literatur}

Arief, Barda Nawawi, 1996, Bunga Rampai Kebijakan Hukum Pidana, Citra Aditya Bakti, Bandung.

Arief, Barda Nawawi, Kapita Selekta Hukum Pidana, 2007, Universitas Diponegoro, Semarang,

Chazawi, Adami, 2002, Pelajaran Hukum Pidana Bagian I, Raja Grafindo Persada, Jakarta

Gunakaya, Widiada dan Petrus Irianto, 2012, Kebijakan Kriminal Penanggulangan Tindak Pidana Pendidikan, Alfabeta, Bandung.

Ismawan, Indra, Money Politics Pengaruh Uang Dalam Pemilu, Yogyakarta, Penerbit Media Presindo, 1999.

Lopa, Baharudin 2001, Kejahatan Korupsi dan Penegakan Hukum, Kompas, Jakarta

Muladi dan Barda Nawawi Arief, 2005, Teori - Teori dan Kebijakan Pidana, Alumni, Bandung.

Soemitro, Hanitijo Ronny. 1990. Metodologi Penelitian Hukum, Jakarta: Ghalia Indonesia.

Sumartini, L, Money Politics dalam Pemilu, Jakarta Badan Kehakiman Hukum Nasional Departemen Kehakiman dan Hak Asasi Manusia, 2004.

\section{Peraturan Perundang - undangan}

Indonesia, Departemen Pendidikan dan Kebudayaan, Kamus Besar Bahasa Indonesia, Jakarta: Balai Pustaka, Edisi kedua, 1994

$$
\begin{aligned}
& \text { Indonesia, UNDANG - UNDANG DASAR } \\
& \text { NEGARA REPUBLIK } \\
& \text { INDONESIA tahun } 1945 . \\
& \text { Indonesia, Undang - Undang nomor } 15 \\
& \text { tahun } 2011 \text { tentang } \\
& \text { Penyelenggara Pemilihan } \\
& \text { Umum. }
\end{aligned}
$$

Indonesia, Undang - Undang nomor 8 tahun 2012 tentang Pemilu Anggota DPR/DPRD PROV/DPRD Kab/Kota

Komisi Pemilihan Umum, Peraturan Komisi Pemilihan Umum nomor 6 tahun 2013 tentang Perubahan Keempat Peraturan KPU nomor 7 tahun 2012 tentang Tahapan, Program dan Jadual Pemilu Anggota DPR, DPD dan DPRD

Komisi Pemilihan Umum, Peraturan Komisi Pemilihan Umum nomor 7 tahun 2013 tentang Pencalonan Anggota DPR, DPRD Provinsi dan DPRD Kabupaten/Kota

Komisi Pemilihan Umum, Peraturan Komisi Pemilihan Umum nomor. 13 tahun 2013 tentang Perubahan Atas Peraturan Komisi Pemilihan Umum nomor 7 tahun 2013 tentang Pencalonan Anggota $D P R, D P R D$ Provinsi dan DPRD Kabupaten/Kota

\section{Internet}

Fenomena Money Politic di Indonesia dalam Perspektif Sosiologi, Tugas Makalah, Jurusan Hubungan Internasional, Fakultas IImu Sosial dan IImu Politik, Universitas Muhamadiyah Malang.

Palimari, H. M. Tarid, Mewujudkan Penegakan Hukum yang Bermartabat, artikel. 